\title{
Pretibial Myxedema, Nodular Variant: Unique Presentation and Clinical Course
}

\author{
Rand Abou Shaar, Shereen Zia, Mohamed Alhamar and Adrian Ormsby* \\ Department of Pathology and Laboratory Medicine, Henry Ford Health System, Detroit, USA
}

Submission: March 14, 2020; Published: April 03, 2020

*Corresponding author: Adrian Ormsby, Department of Pathology and Lab Medicine, Henry Ford Health System, Detroit, USA

\begin{abstract}
Literature has shown morphological diversity in the presentation and occurrence of pretibial myxedema following I-131 treatment. We present a case of a 47 y.o African American male with post I-131 hypothyroidism for Graves disease that presented with enlarging bilateral lower extremity and ankle lesions. Examination revealed firm, tender, hemispherical, large, hyperpigmented nodules. Ultrasound demonstrated nonspecific hypovascular nodular thickening of the skin. Excisional biopsy showed reactive dermal and subcutaneous fibrosis with dermal mucinosis. Alcian blue stain confirmed the diagnosis. Graves' dermopathy is generally rare, with the nodular variant accounting for $10 \%$ of cases. Our case reflects a variable appearance of post-I-131 treatment dermopathy partially resistant to the multimodal treatment.
\end{abstract}

Keywords: Myxedema; Nodular Variant; Hypothyroidism; Dermopathy

Abbreviations: Radioactive iodine (I-131)

\section{Introduction}

Graves dermopathy is a rare entity (approximately 4\%), with the nodular variant accounting for $10 \%$ of all reported cases [1]. Many patients with Graves' disease receive radioactive iodine (I-

131) as a treatment. Literature has shown morphological diversity in the presentation and occurrence of pretibial myxedema following I-131 for Graves' disease [2]. Case Report
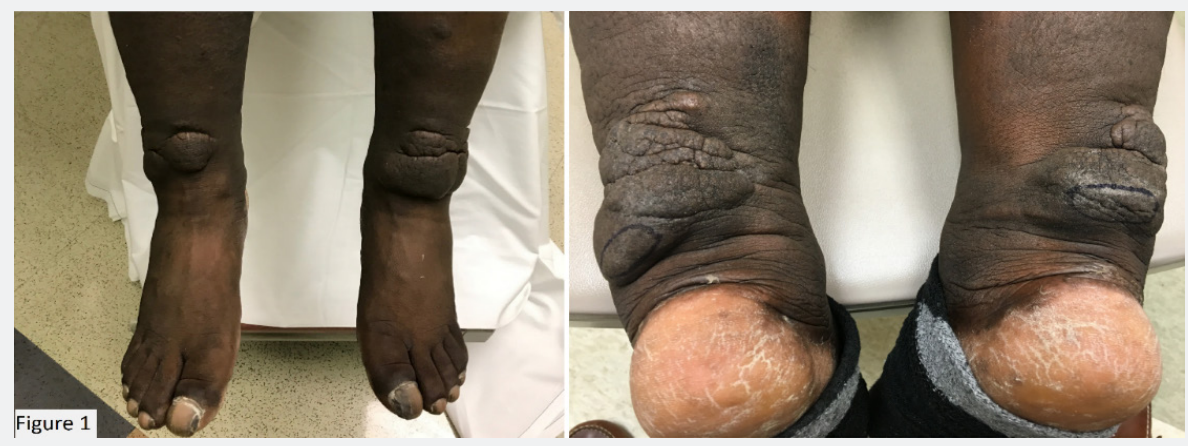

Figure 1: Bilateral ankles and distal extremities showing firm, hyperpigmented, keloid-like nodules.

A 47 year-old African American male presented with complaints of bilateral lower extremity and ankle lesions that developed after receiving radioactive ablation 20 years ago for his Graves' disease. The lesions were causing constant discomfort and preventing him from wearing shoes. Examination revealed bilateral large firm, tender, hemispherical and hyperpigmented nodules at the distal portion of his lower extremities and ankles (Figure 1). Other findings include mild edema and Graves' opthalmopathy. His lab tests revealed elevated thyrotropinstimulating hormone levels at $15.94 \mathrm{mIU} / \mathrm{mL}$ and suppressed free 
thyroxine (T4) levels at $0.69 \mathrm{ng} / \mathrm{dL}$ consistent with his history of noncompliance. A previous ultrasound on the lesions showed nonspecific findings of hypovascular areas of diffuse nodular dermal soft tissue thickening involving both ankles. A decision to preform an extensive excisional biopsy of his left ankle lesions with skin grafting was made. Microscopically, the lesion showed reactive dermal and subcutaneous fibrosis with dermal mucinosis (Figure 2). A positive Alcian blue stain confirmed the diagnosis of pretibial myxedema (Figure 3). The excision measured 17x $7 \mathrm{~cm}$.

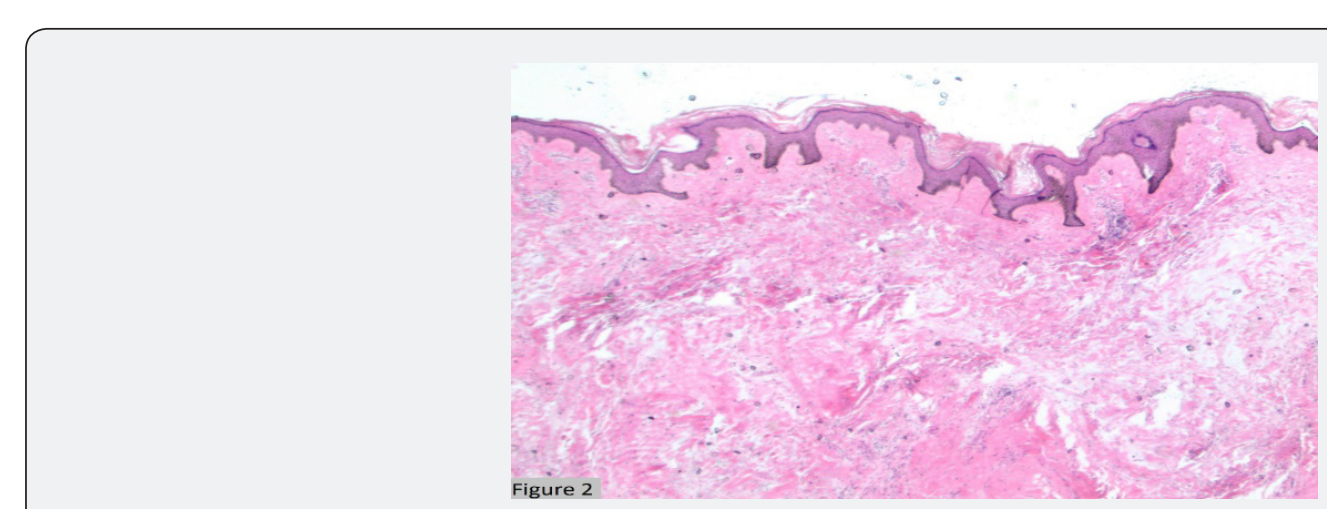

Figure 2 Hematoxylin and Eosin stained slide shows dermal mucinosis.

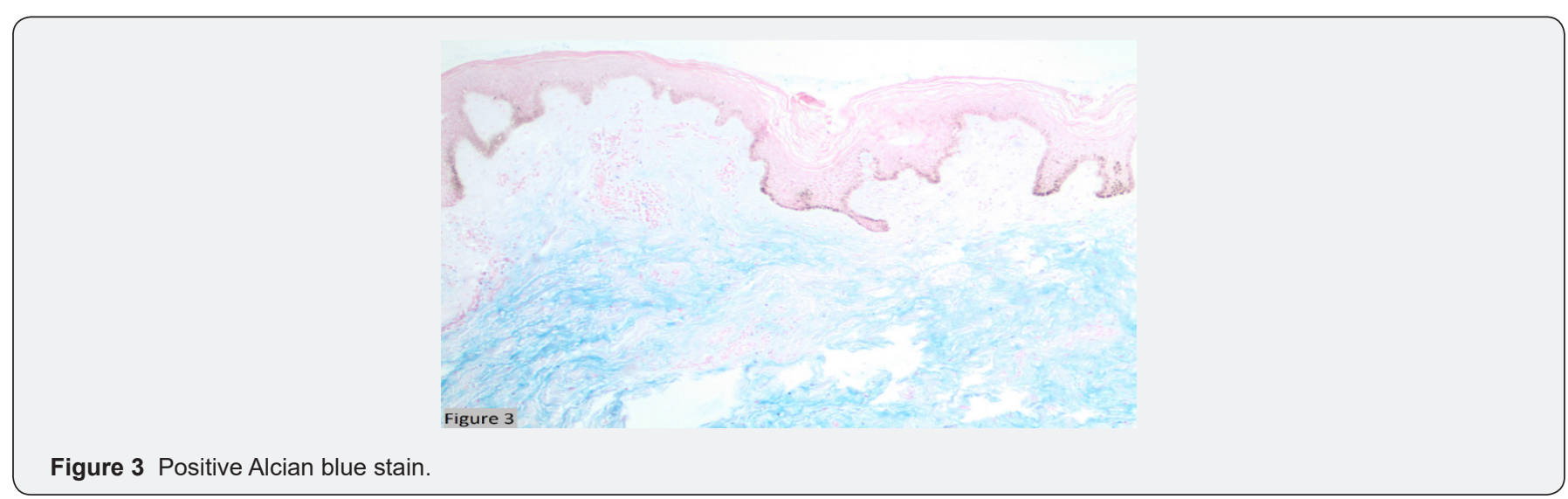

\section{Discussion}

Pretibial myxedema, or thyroid dermopathy, is an infiltrative dermopathy occurring as a result of excess glycosaminoglycan deposition in the dermis and subcutis. This process is stimulated by thyrotropin receptor antibody-mediated cytokine release and activated Th1 cells [3]. Classical clinical manifestation includes peau d'orange appearance and non-pitting edema. These lesions are usually confined to the pretibial area but can occur at any other sites. The differential diagnosis includes erythema nodosum, keloid, and stasis dermatitis. Nodular variant of pretibial myxedema is generally considered self-limited. However, our case presents the variable appearance of post-radioactive iodine treatment dermopathy that was partially resistant to multimodal treatment approach.

\section{References}

1. Changgui Lan, Yi Wang, Xia Zeng, Jing Zhao, and Xiaoxi Zou (2016) Morphological Diversity of Pretibial Myxedema and Its Mechanism of Evolving Process and Outcome: A Retrospective Study of 216 Cases. Journal of Thyroid Research 2016 (3): 1-23.

2. David Bronsky, Rosario Kiamko, Sheldon S Waldstein, (1969) Relative Occurrence After Treatment of Hyperthyroidism by Radioactive Iodine (131I) or Subtotal Thyroidectomy Arch Intern Med 121(2): 113-117.

3. Ajjan RA, Watson PF, Weetman AP (1996) Cytokines and thyroid function. Adv Neuroimmunol 6(4): 359-386. 


\section{Your next submission with Juniper Publishers} will reach you the below assets

- Quality Editorial service

- Swift Peer Review

- Reprints availability

- E-prints Service

- Manuscript Podcast for convenient understanding

- Global attainment for your research

- Manuscript accessibility in different formats ( Pdf, E-pub, Full Text, Audio)

- Unceasing customer service

Track the below URL for one-step submission https://juniperpublishers.com/online-submission.php 